\title{
Analysis of Carotenoids and Identification of Mangrove Sediment Bacteria of Segara Anakan, Cilacap
}

\author{
Riyanti ${ }^{1 *}$, Meris Rahmawati ${ }^{1}$, Nuning Vita Hidayati ${ }^{1}$, Agung Dhamar Syakti ${ }^{2}$ and \\ Ocky Karna Radjasa ${ }^{3}$ \\ ${ }^{1}$ Faculty of Fisheries and Marine Science, Jenderal Soedirman University \\ Jl. dr. Soeparno Karangwangkal, Purwokerto, 53122, Indonesia \\ ${ }^{2}$ Center of Maritime Bioscience Study, Jenderal Soedirman University \\ Jl. dr. Soeparno Karangwangkal, Purwokerto, 53122, Indonesia \\ ${ }^{3}$ Faculty of Fisheries and Marine Science, Dipenogoro University \\ Jl.Prof.H.Soedarto, S.H.Tembalang, Tembalang, Semarang, 50275, Indonesia \\ Email: riyanti.anti@gmail.com
}

\begin{abstract}
The excessive consumption of artificial dyes can lead to negative effects on human body. Thus, the invention of natural dyes, such as carotenoids, is needed in order to reduce the negative impacts. Carotenoids are yellow, orange, and reddish yellow pigments produced by plants, animals, algae, and microorganisms. This study was aimed to analyze the carotenoid pigments of mangrove sediment bacteria in Segara Anakan, Cilacap, and to identify species of bacteria that can produce carotenoids. Carotenoids were analysed by using Thin Layer Chromatography (TLC) and UV-Vis spectrophotometer. Meanwhile molecular identification of bacteria was carried by $16 S$ rDNA PCR and DNA sequence was analysed through a program called Basic Local Alignment Search Tool (BLAST). The kinship of bacteria was shown in Phylogenetic tree by using Bioedit and MEGA 5 software. Qualitative analysis by using TLC produced several pigments like: $\beta$-carotene, $\beta$-isorenieraten, lycopene, flavonoids, chlorophyll a, chlorophyll $b$ and a feofitin with Rf value of 0.36-0.95. Quantitative analysis showed that bacteria KH (greenish yellow), KT (dark yellow) and KM (light yellow) produced carotenoids at $95.30 \mu \mathrm{g} . \mathrm{g}^{-1}$, $110.34 \mu \mathrm{g} . \mathrm{g}^{-1}$ and $25.349 \mu \mathrm{g} . \mathrm{g}^{-1}$. KH, KT and KM were suspected to be bacteria known as Streptomyces chartreusis, Bacillus megaterium and Streptomyces chromofuscus with similarity of 99\%. Mangrove sediment bacteria had the potential of producing carotenoids as an alternative of eco-friendly natural dyes.
\end{abstract}

Keywords: pigment, Streptomyces, Bacillus, natural dyes

\section{Introduction}

In the market, dyes are very often added to food. The use of dyes that is excessive, inappropriate and harmful needs to be avoided because it can have negative impacts on health. Natural dyes can be used as an alternative solution in dealing with the harmful effects of the use of artificial dyes. Natural dyes can be obtained from plants, animals, micro-algae (cyanobacteria), heterotrophic and phototrophic bacteria, and fungi (Britton, 1998; Kurniawan et al., 2010; Gupta et al., 2011). Natural dyes that have been mass produced are $\beta$-caroten from Dunaliella, astaxanthin from Haematococcus, and lutein from Chlorophycea (Campo et al., 2007). Bacteria that are known to be the producers of carotenoid are Streptomyces sp., Brevibacterium maris, Paracoccus alcaliphilus, Rhodotorula rubra, Bradyrhizobium sp. (Hannibal et al., 2000; Simova et al., 2004; Baskar et al., 2010; Arlita et al., 2013).
Bacteria are potential organisms utilized in the health and industry sector. Natural color pigment or substance that can be produced by bacteria has positive impacts on human health. Palanichamy et al. (2011) said Streptomyces sp. isolated from sediments on the coast of Chennai, India, is potential as a pigment producer. The new acyclic carotenoids and monocyclic $\mathrm{C}_{40}$ carotenoids were isolated from the novel Gram-negative bacterium Rubritalea squalenifaciens and novel species of Gram-negative bacteria belonging to the family Flavobacteriaceae, phylum Bacteroidetes respectively (Shindo and Misawa, 2014).

The utilization of bacteria as the producers of carotenoid pigment can be an alternative to gain dyes that are eco-friendly and safe to be consumed by human. This research is aimed to analyse carotenoid pigment produced by mangrove sediment bacteria of Segara Anakan, Cilacap and to identify bacteria that can produce carotenoid pigment. 


\section{Material and Methods}

The content of carotenoid was measured by spectrophotometry method (Dharmaraj et al., 2009). Carotenoid was extracted in accordance with Dharmaraj et al. (2009) with modifications. Bacterial isolates were inoculated in a starch casein medium with $\mathrm{pH} 7$ of $100 \mathrm{ml}$, and incubated in a shaker with a rotation speed of $180 \mathrm{rpm}$ and temperature of $28^{\circ} \mathrm{C}$ for 120 hours. Furthermore, the solution was centrifuged at $6000 \mathrm{rpm}$ for 15 minutes. Bacterial cells were taken and extracted by using maceration method with acetone and methanol (7:3). Then, the extract is centrifuged and dried by using nitrogen gas.

\section{Measurement of carotenoid's quality}

Carotenoid's quality of bacterial isolates was measured by employing TLC (Dharmaraj et al., 2009; Baskar et al., 2010). Adsorbent or plate used in TLC was silica gel $60 \mathrm{~F}_{254}$. The qualification of control of the TLC used mobile phase variations, that were: methanol: chloroform $(1: 7, \mathrm{v}: \mathrm{v})$ methanol: chloroform $(1: 5, v: v), \quad$ methanol:chloroform (1:9,v:v), hexane: methanol $(5: 5, v: v)$ hexane:methanol $(3: 7, \mathrm{v}: \mathrm{v})$ hexane:methanol $(1: 9, \mathrm{v}: \mathrm{v})$. The results were visualized on a $254 \mathrm{~nm}$ UV light. The analysis of carotenoid's quality with Rf (Retardation factor) value:

$$
\mathrm{Rf}=\frac{\text { migration distance of extract }}{\text { migration distance of solvent }}
$$

\section{Meaurement of carotenoid's quantity}

Meaurement of carotenoid's quantity (Sahara et al., 2013), was done by using UV-Vis Scan Spectrophotometer with a wavelength of 400-600 $\mathrm{nm}$. Total carotenoid was counted by using sample comparison with the standard of $\beta$-carotene curve (Musfiroh et al., 2008).

\section{Molecular identification of mangrove sediment bacteria that produce carotenoids}

DNA was extracted in accordance with Margavey et al. (2004) with modification. A total of 1 $\mathrm{ml}$ of liquid culture of bacteria was put into a $1.5-\mathrm{mL}$ tube, and then it was centrifuged for $5 \mathrm{~min}$. Next, pellet was homogenized with $400 \mu \mathrm{ITE}$ and, again, centrifuged for $5 \mathrm{~min} .400 \mu \mathrm{l}$ of SET solution and 50 $\mu \mathrm{l}$ of Lysozim solution were added and incubated at a temperature of $37^{\circ} \mathrm{C}$ for $1 \mathrm{~h} .50 \mu$ of SDS solution were added and then incubated at a temperature of $65^{\circ} \mathrm{C}$ for $1 \mathrm{~h}$. Furthermore, $167 \mu \mathrm{l}$ of $\mathrm{NaCl}$ solution were added and incubated at the the temperature of $65^{\circ} \mathrm{C}$ for $1 \mathrm{~h} .400 \mu \mathrm{l}$ of cool chloroform solution were added and then incubated at room temperature for $30 \mathrm{~min}$. After $30 \mathrm{~min}$, the mixture was centrifuged for 10 minutes and supernatant obtained was moved to a new tube and then a solution of isopropanol in the ratio of 1:1 was added and incubated at $-20^{\circ} \mathrm{C}$ for $24 \mathrm{~h}$. The samples then were centrifuged for $5 \mathrm{~min}$. The pellet was homogenized with cool ethanol $70 \%$. The ethanol was evaporated and the pellet formed was dried by wind. The pellet then was resuspended with $50 \mu$ l of TE solution.

The amplification of $16 S$ rDNA PCR fragment was done toward isolates that potentially had carotenoids by using primer R1492 (5'TACGGCTACCTTGTTACGACTT-3') and F27 (5'AGAGTTTGATCCTGGCTCAG-3'). The composition of

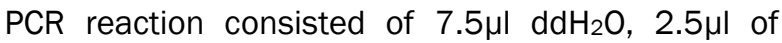
genomIC DNA (50 ng. $\mathrm{l}^{-1}$ ), 1.25 $\mu$ l of primer F27 (25 pmol), $1.25 \mu \mathrm{l}$ of primer R1492 (25 pmol), and $12.5 \mu l$ of KAPPA MIX PCR (Margavey et al., 2004). The composition was modified by by Riyanti et al. (2009).

DNA was amplified by employing an initial denaturation program at a temperature of $80^{\circ} \mathrm{C}$ for 5 minutes; 30 cycles that consisted of: denaturation $\left(94^{\circ} \mathrm{C}\right.$ for $\left.30 \mathrm{sec}\right)$, annealing $\left(55^{\circ} \mathrm{C}\right.$ for 30 seconds), polymerisation $\left(72^{\circ} \mathrm{C}\right.$ for $\left.60 \mathrm{sec}\right)$, and last polymerisation at a temperature of $72^{\circ} \mathrm{C}$ for $7 \mathrm{~min}$. The result of amplification was analysed by employing electrophoreses, that was $2 \%$ agarose and a dye ethidium bromide (Margavey et al., 2004).

The results of DNA sequences in bacteria were compared to DNA sequences in the DNA data center. The search was performed with the Basic Local Alignment Search Tool (BLAST) at the National Center for Biotechnology Information, National Institute for Health, USA (www.ncbi.nlm.nih.gov) (Atschul et al., 1997). Then, a phylogenetic tree was made from DNA sequent by employing Bioedit and MEGA 5 software (Zhang et al., 2008).

\section{Result and Discussion}

\section{Analysis of carotenoid pigments}

Observations based on the color samples of the bacterium used three test samples. Bacteria that contained carotenoid pigments had several color (Figure 1.).

The value of Rf (Table 2.) shows that the extract with $\mathrm{KH}$ code allegedly contained $\beta$-carotene, flavonoids, feofitin a, chlorophyll $a$, and chlorophyll $b$ pigment. The one with KT code was suspected to contain $\beta$-carotene, flavonoids, and chlorophyll a pigment. While extract with $\mathrm{KM}$ code was suspected to contain $\beta$-Isorenieraten pigment, chlorophyll a, chlorophyll $\mathrm{b}$ and lycopene pigment. Then this 


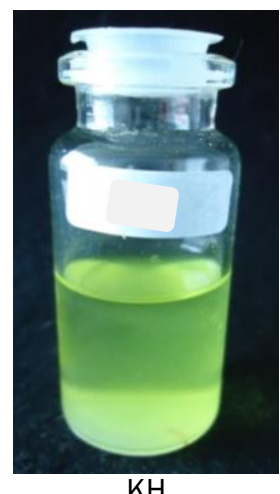

$\mathrm{KH}$

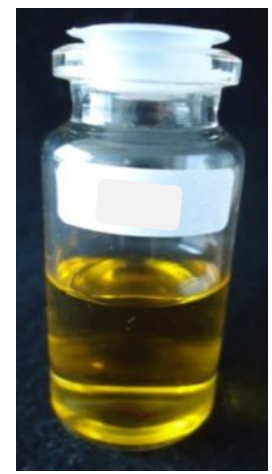

KT

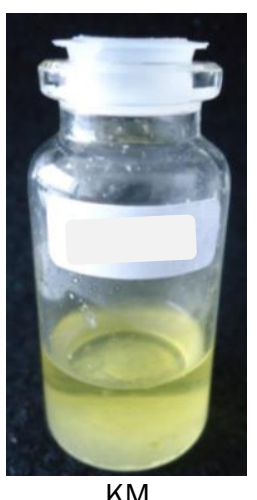

Figure 1. Pigment of the result of sediment bacteria extraction $(\mathrm{KH})$ greenish yellow, $(\mathrm{KT})$ dark yellow, (KM) light yellow.

research would only discuss about carotenoid pigment groups that were $\beta$-carotene, $\beta$ Isorenieraten, and lycopene. The movement of nonpolar carotene was faster, marked with the higher Rf than that of other pigments (Rizkina et al., 2013) so that easily identified trough visual observation. According to Gross (1991), yellow-orange dye is a sign of carotene pigment group, green-blue is chlorophyl a, while light yellow is xanthophyll pigment group. Carotenoids are divided into two main groups namely polar carotenoid (xanthophill) and non-polar carotenoid non polar (carotene).

The result of TLC was confirmed by employing UV-Vis spectrophotometer. Based on the analisys of the rough extract of $\mathrm{KH}, \mathrm{KT}$ dan $\mathrm{KM}$ pigment, a spectrum pattern with 3 peaks in the wavelength of $400-600 \mathrm{~nm}$ (Figure 2.) could be obtained. They were indicated as a carotenoid pigment (Sahara et al., 2013).

The result of measurement shows that $\mathrm{KH}$ extract was indicated for containing carotenoid pigment with three peaks, which were 468.5, 439.5 and $416.0 \mathrm{~nm}$. KT extract shows that maximum wavelengths were $653.5,474.5$ and 364.5. In addition, apparently KM extract contained carotenoid pigment that had wavelengths of 467.5 , 439.0 and 416.0. Those three extracts samples are included in carotenoid wavelength category, which is 400-600 nm (Sahara et al., 2013). Besides the comparation between the wavelength of the samples and that of the references, the fathoming of carotenid content was also held by comparing the curve of spectrophotometer with the standart carotenoid curve of Laughlin et al. (2002). Laughlin et al. (2002) states that pure $\beta$-carotene, when it is measured with the wavelength of $210-700 \mathrm{~nm}$, shows a peak in the wavelength of $452 \mathrm{~nm}$.

It is supported by Barredo (2012) who explain that maximum wavelengths of $\beta$-carotene pigment's are 430, 453 and $447 \mathrm{~nm}$; those of Lycopene are 445, 457 and $504 \mathrm{~nm}$; those of Zeaxanthin are 427, 453 and $447 \mathrm{~nm}$; and those of Lutein are 427, 448 and $472 \mathrm{~nm}$. While Cantaxanthin and Astaxanthin only has one maximum wavelenght, that is 470 and $477 \mathrm{~nm}$, repectively. The result of $\beta$-carotene degree determining by using ray spectroskopy method appeared on the pigment of sediment bacteria as shown on Figure 3 and Table 2.

The regression equation for the curve above in the concentration range of $5-50 \mathrm{ppm}$ was $y=$ $0.0662 x-0.0068$ with $R^{2}=0.99$. the result shows that the level of beta carotene of KT was higher than that of $\mathrm{KH}$ and $\mathrm{KM}$. $\beta$-carotene concentration in $\mathrm{KH}$ and KT were exceed the "limit of quantification" while the concentration of KM could be counted accurately. The problem related to the limited supply of rough extract of bacteria that produced $\mathrm{KH}$ and $\mathrm{KT}$ pigment curbed us in validating the consentration of $\beta$-carotene of $\mathrm{KH}$ dan KT extract. KT extract's level of $\beta$-carotene is higher than that of other extracts seen from the consentration of the measurement result by using regression equation. Besides, the dark yellow dye owned by KT extract indicated that its carotene content was high. It is supported by Britton et al. (1995) that carotene pigment has orange hue. The production of pigment by microorganisms is affected by several factors such as $\mathrm{pH}$, temperature, source of carbon and nitrogen, and time of incubation (Chintapenta et al., 2012).

Carotenoid content produced by $\mathrm{KH}, \mathrm{KT}$ and $\mathrm{KM}$ bacteria was less than that produced by Micrococcus sp. Isolated from the sediment, Canada. A research conducted by Ibrahim (2008) shows that Micrococcus sp. produces $430 \mu \mathrm{g} . \mathrm{g}^{-1}$ of carotenoid. It means sediment bacteria can produce carotenoid more than carrot and purple carrot, that is between 200 and $300 \mu g . g^{-1}$ (Lee et al., 2011). Ibrahim (2008) says that there are some factors affect the production of carotenoid besides light, 
that are $\mathrm{pH}$, rate of centrifuge and the temperature of incubation.

\section{Identification of sediment bacteria producing carotenoid pigment}

Bacteria used in the process of identification were labelled KM, KH and KT. KT bacteria (Figure 4.) were assumed as a part of Bacillus megaterium and the level of similarity was $99 \%$. The result of the research shows that Bacillus megaterium could produce dark yellow pigment. Based on the research held by Mitchell et al. (1986) in Khaneja et al. (2009) it is known that Bacillus megaterium can produce red pigments. According to Khaneja et al. (2010) there are some Bacillus spesies that can produce carotenoid, such as $B$. marisflavi, $B$. indicus, $B$. firmus, $B$. altitudinis and $B$. safensis with yellow, orange and pink detected on the wave length of 455,467 and $492 \mathrm{~nm}$. It is supported by the research of Duc et al. (2006) that discovers Bacillus indicus produces yellow carotenoid. Nugraheni et al. (2010) in their research about the characteristic of carotenoid of bacterial symbionts in seagrass, Thalassia hemprichii, find that $B$. licheniformis produces orange carotenoid. Bacillus Genus produce carotenoid pigment with optimum $\mathrm{pH}$, that is 7 (Khaneja et al., 2010).

$\mathrm{KM}$ and $\mathrm{KH}$ bacteria were Streptomyces chromofuscus and S.chartreusis that were 99\% similar. Some types of Streptomyces that have been examined previously are also reported for containing certain kinds of carotenoid for instance the one identified by Dharmaraj et al. (2009), Streptomyces sp., isolated from Callyspongia diffusa sponge produces lycopene pigment with the maximum wave length is $445 \mathrm{~nm}$ and it's Rf value is 0.40 . Next, Dharmaraj et al. (2009) found Streptomyces strain (AQBMM35) spesies from Mycale mytilorum sponge as the producer of phytoene pigment with Rf value was 0.81. Palanichamy et al. (2011) isolated

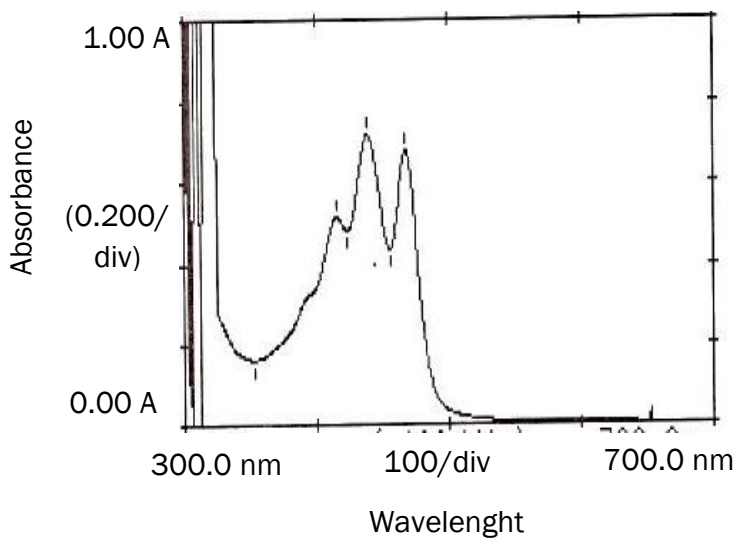

(a)

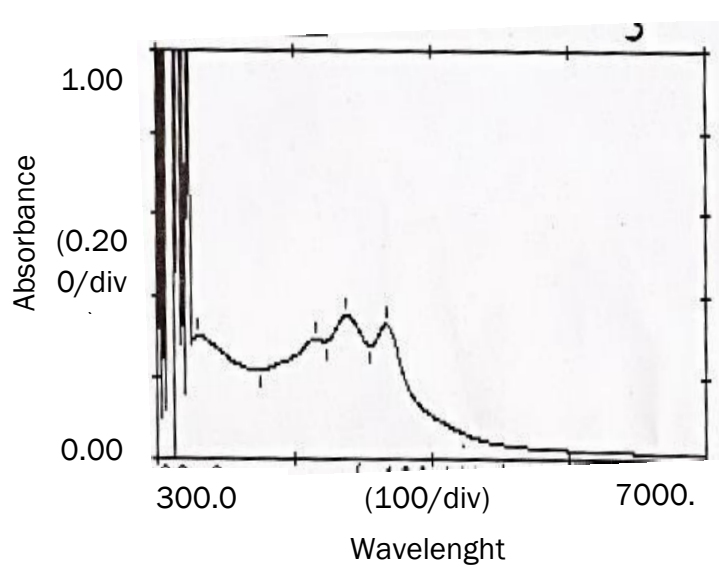

(c)

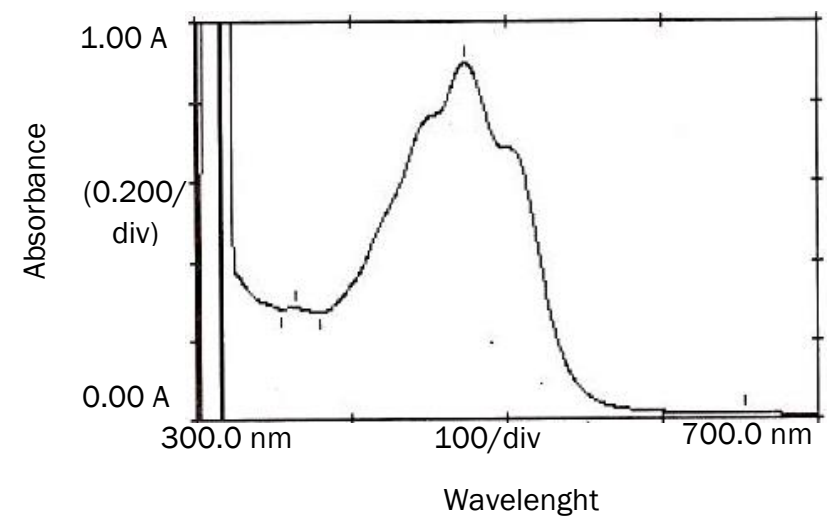

(b)

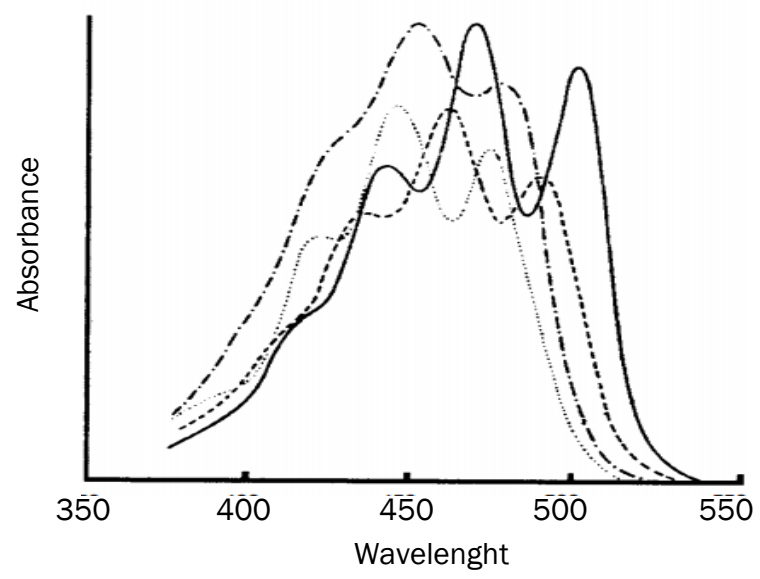

(d)

Figure 2. The result of absorbance of UV-Vis spectrophotometer (a) KH extract (b) KT extract (c) KM extract (d) absorbance spectrum of lycopene (_ $), \gamma$-carotene ( $\ldots \ldots$ - $), \beta$-carotene $(. . .),. \alpha$-carotene ( 2001) 
Table 1. Fathoming of kind of pigment based on Rf value by using TLC

\begin{tabular}{clllllc}
\hline Isolate & Spot & \multicolumn{1}{c}{ Color } & Rf value & fathoming Pigmen Type & Literature & Reference \\
\hline KH & 1 & Yellow & 0.94 & $\beta$-carotene & $0,94-0,97$ & Ati et al. (2006) \\
& 2 & Yellow & 0.86 & Flavonoid & $0,86-0,89$ & Ati et al. (2006) \\
& 3 & Grey & 0.8 & pheophytin a & $0.74-0.82$ & Heriyanto and Limantara (2006) \\
& 4 & Grey & 0.64 & chlorophyl a & $0,57-0,64$ & Heriyanto and Limantara (2006) \\
& 5 & Bluish green & 0.6 & chlorophyl a & $0,57-0,64$ & Heriyanto and Limantara (2006) \\
& 6 & Yellow & 0.48 & chlorophyl b & $0,48-0,56$ & Heriyanto and Limantara (2006) \\
& 1 & Dark yellow & 0.94 & B-carotene & $0,94-0,97$ & Ati et al. (2006) \\
& 2 & Grey & 0.64 & chlorophyl a & $0,57-0,64$ & Heriyanto and Limantara (2006) \\
& 3 & Bluish green & 0.6 & chlorophyl a & $0,57-0,64$ & Heriyanto and Limantara (2006) \\
& 4 & Light yellow & 0.36 & Flavonoid & $0,32-0,40$ & Ati et al. (2006) \\
& 1 & Dark yellow & 0.95 & B-lsorenieratene & - & Baskar et al. (2010) \\
& 2 & Bluish green & 0.6 & chlorophyl a & $0,57-0,64$ & Heriyanto and Limantara, (2006) \\
& 3 & Yellow & 0.48 & chlorophyl b & $0,48-0,56$ & Heriyanto and Limantara, (2006) \\
& 4 & Light brown & 0.40 & Lycopene & - & Dharmaraj et al. (2009) \\
\hline
\end{tabular}

Tabel 2. Level of $\beta$-carotene pigment of mangrove sediment bacteria

\begin{tabular}{ccc}
\hline Sample & Absorbance & Level of $\beta$-carotene $\left(\mu \mathrm{g} . \mathrm{g}^{-1}\right)$ \\
\hline KH & 0.721 & 95.30 \\
KT & 0.899 & 110.34 \\
KM & 0.354 & 25.34 \\
\hline
\end{tabular}

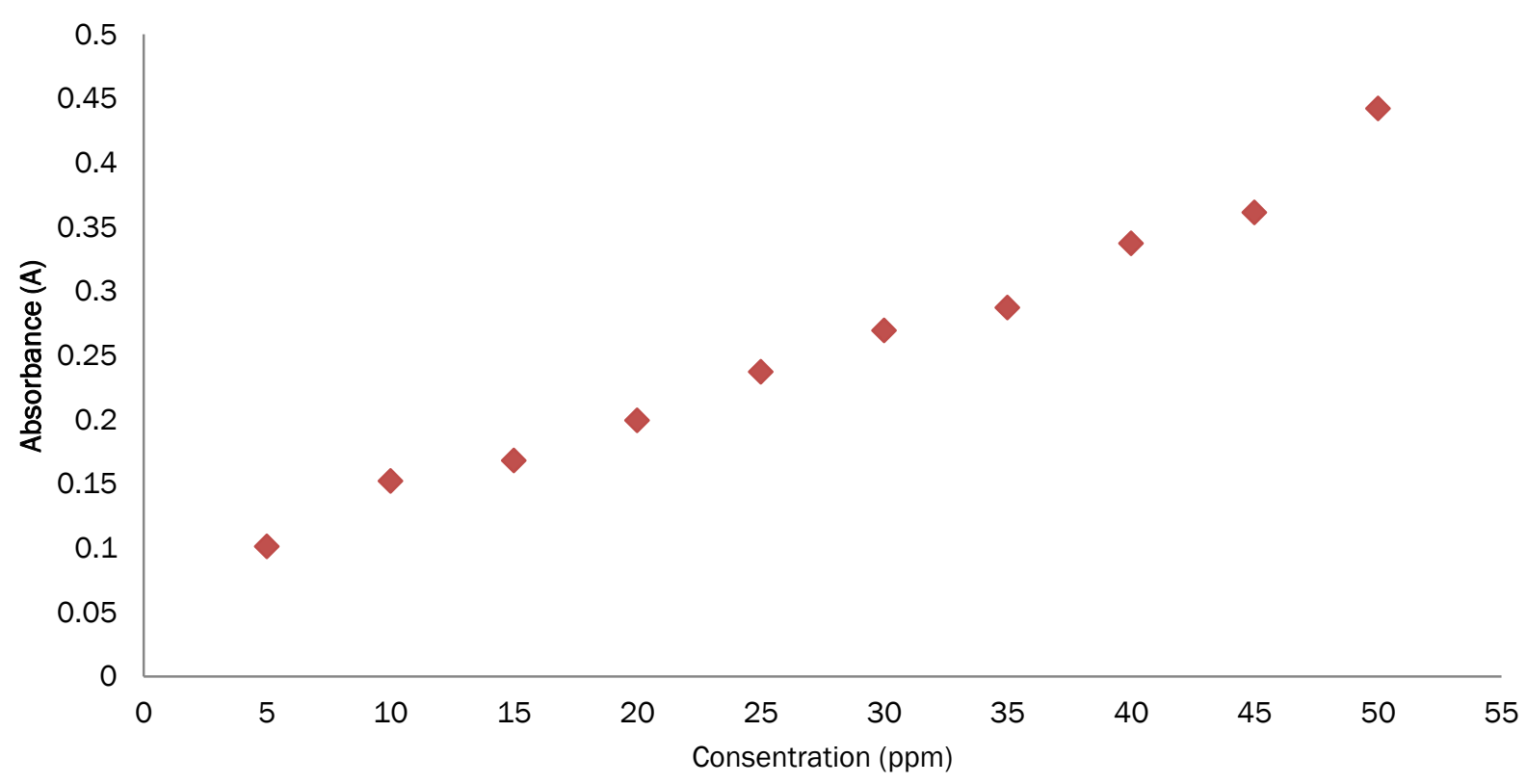

Figure 3 . The curve of $\beta$-carotene calibration

S.coelicolor and S. violaceoruber bacteria from the sediment of sea and soil in India as the producers of actinorhodin pigment that has red-blue dye. Bose et al. (2013) in their research state that Streptomyces sp. T1027, lighted by a lamp during the culture, can produce $\beta$-carotene pigmen. Baskar et al. (2010) also discovered that Streptomyces sp. isolated from some spesies of fish such as Tendania anhelan, Epinephelus diacanthus, Cyprinus carpio and Osepherenemous gourami can produce several tyoes of carotenoid like phytoene, phytofluene, $\alpha$ carotene, $\beta$-carotene and $\beta$-isorenieratene. 


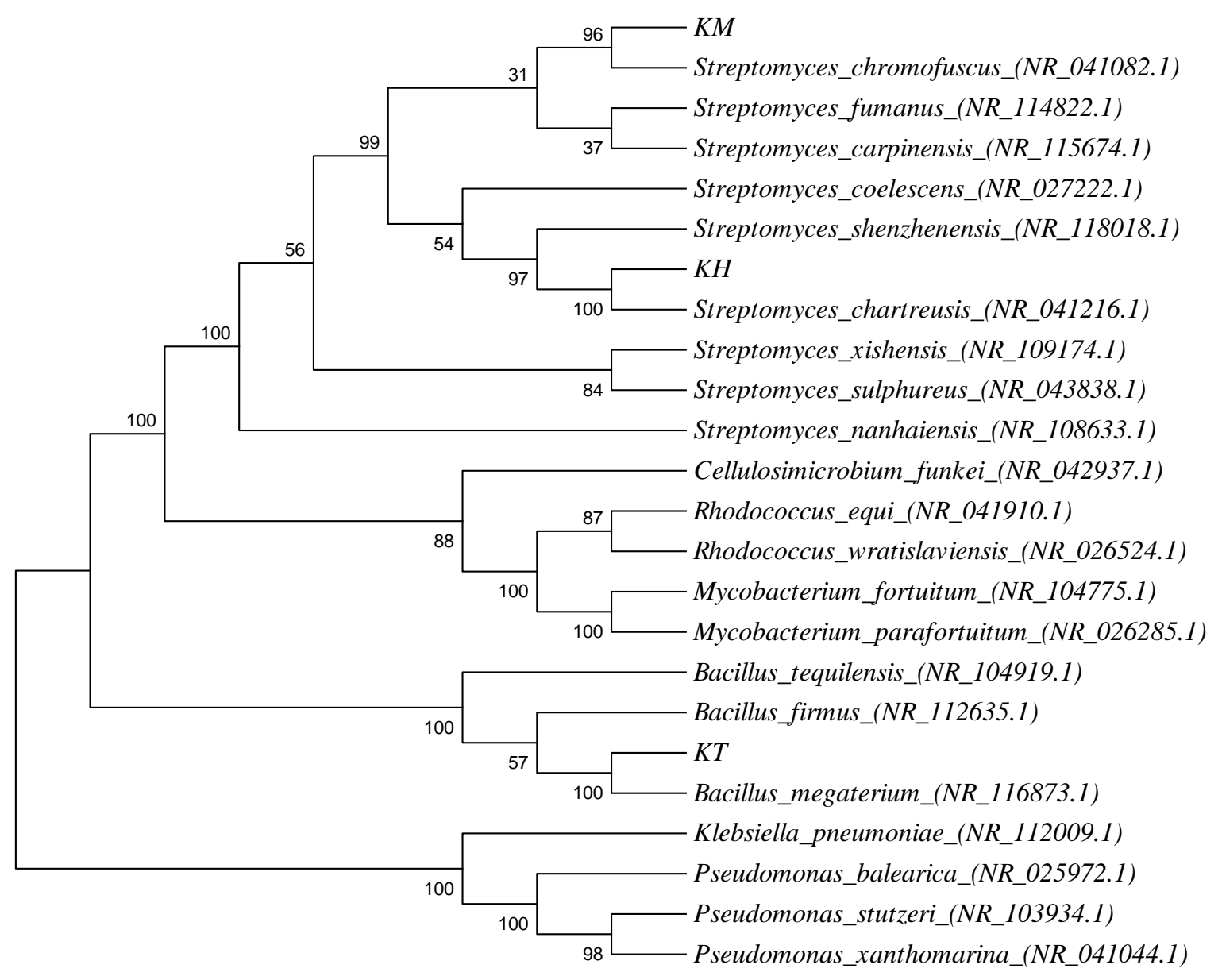

Figure 4. Genetic relation of mangrove sediment bacteria. The formation of dendogram was based on PCR 165 rDNA. For the sequence aligment ClustalW Multiple Aligment was employed. While for the analisys, the researcher used Neighborjoining, phylogeny test with Boostrap method and 1000 repetitions, as well as kimura 2-parameter model.

\section{Conclusion}

Mangrove sediment bacteria of Segara Anakan-Cilacap could produce carotenoid pigment of carotene group, which were $\beta$-carotene, $\beta$ isorenieratene and lycopene. $\mathrm{KH}, \mathrm{KT}$ and $\mathrm{KM}$ bacteria were known can produce carotenoid sebesar $95.30 \mu \mathrm{g} . \mathrm{g}^{-1}, 110.34 \mu \mathrm{g} . \mathrm{g}^{-1}$ and $25.34 \mu \mathrm{g} . \mathrm{g}^{-1}$. The result of identification shows that KT, KM and $\mathrm{KH}$ bacteria had similarity with Bacillus megaterium, Streptomyces chromofuscus and Streptomyces chartreusis.

\section{Acknowledgement}

The writers would like to thank Research and Community Service Institute (LPPM) through Institutional Research and DIPA of Jenderal Soedirman University as the source of fund. Thank is also delivered specifically to Rahmawati $M$, who had helped in producing data related to the isolation of sediment bacteria and the characterization of caretonoid pigment in the research of her thesis.

\section{References}

Altschul, S.F., Madden, T.L., Schäffer, A.A., Zhang, J., Zhang, Z., Miller, W. \& Lipman, D.J. 1997. Gapped BLAST and PSI-BLAST: a new generation of protein database search programs. Nucleic Acids Res. 25(17):33893402. doi: 10.1093/nar/25.17.3389.

Arlita, N.R., Radjasa, O.K. \& Santoso, A., 2013. Identifikasi Pigmen Karotenoid Pada Bakteri Simbion Rumput Laut Caulerpa Cupressoides (Vahl) C. Agardh. J. Mar. Res. 2(3):68-77.

Ati, N.H., Rahayu, P., Notosoedarmo, S. \& Limantara, L. 2006. Komposisi dan Kandungan Pigmen 
Tumbuhan Pewarna Alami Tenun Ikat di Kabupaten Timor Tengah Selatan, Propinsi Nusa Tenggara Timur. Indo. J. Chem. 6(3): 325331.

Barredo, J.L. 2012. Microbial carotenoids from bacteria and microalgae. Methods. Mol. Biol. 892: 133-141. doi: 10.1007/978-1-6177 9-879-5_1

Baskar, V., Madhanraj, P., Kanimozhi, K. \& Panneerselvam, A. 2010. Characterization of carotenoids from selected strains of Streptomyces sp. Annals Biol. Res. 1(4): 194200.

Bose, V.S.C., Vishnupriya, B. \& Selvam, K., 2013. Characterization of Marine streptomyces $\mathrm{sp}$. T1027 Producing $\beta$-Carotene Under Light Induction. Am. J. Pharm. Res. 3(3): 1-14.

Britton, G. 1995. UV/visible spectroscopy. In Britton, G., Liaaen-Jensen, S, Pfander, H (eds), Carotenoids: Spectroscopy, vol. 1B. Birkhäuser Verlag. Basel. 63 pp.

Britton, G. 1998. Overview of carotenoid biosynthesis. In: Britton G, Liaaen-Jensen $S$, Pfander $\mathrm{H}$ (eds) Carotenoids: biosynthesis and metabolism. Birkhäuser. Basel, 147 pp.

Campo, J.A.D., García-González, M. \& Guerrero, M.G., 2007. Outdoor cultivation of microalgae for carotenoid production: current state and perspectives. App.Microbial.Biotechnol. 74(6):1 163-1174. doi: 10.1007/s 00253-007-0844-9

Chintapenta, L.K., Rath, C.C., Maringinti, B. \& Ozbay, G., 2014. Culture conditions for growth and pigment production of a Mangrove Penicillium species. J. Multidiscip. Sci. Res. 2: 1-5.

Dharmaraj, S., Ashokkumar, B. \& Dhevendaran, K. 2009. Fermentative Production of Carotenoids from Marine Actinomycetes. Iran J. Microbiol. 1 (4): 36-41.

Duc, L.H., Fraser, P.D., Tam, N.K. \& Cutting, S.M., 2006. Carotenoids present in halotolerant Bacillus spore formers. FEMS Microbiol. Lett. 255(2): 215-224. doi: 10.1111/j.1574-69 68.2005.00091.x

Gross, J. 1991. Pigments In Vegetables (Chlorophylls and Carotenoids).Van Nostrand Reinhold. New York. 75 pp.

Gupta, C., Garg, A.P., Prakash, D., Goyal, S. \& Gupta, S., 2011. Microbes as potential source of biocolours. Pharma. 2: 1309-1318.
Hannibal, L., Lorquin, J., D'Ortoli, N.A., Garcia, N., Chaintreuil, C., Masson-Boivin, C., Dreyfus, B. \& Giraud, E. 2000. Isolation and characterization of canthaxanthin biosynthesis genes from the photosynthetic bacterium Bradyrhizobium sp. Strain ORS278. J. Bacteriol. 182: 3850-3853. doi: 10.1128/JB.182.13.3850-3853.2000

Heriyanto \& Limantara, L. 2006. Komposisi Dan Kandungan Pigmen Utama Tumbuhan Taliputri Cuscuta australis R.Br. dan Cassytha filiformis L. Makara Sains. 10(2): 69-75. doi: 10.7454/ mss.v10i2.183

Ibrahim, A.S.S. 2008. Production of Carotenoids by a Newly Isolated Marine Micrococcus sp. J. Biotechnol. 7(3): 469-474.

Khaneja, R., Perez-Fons, L., Fakhry, S., Baccigalupi, L., Steiger, S., To, E., Sandmann, G., Dong, T.C., Ricca, E., Fraser, P.D. \& Cutting, S.M. 2010. Carotenoids found in Bacillus. J. Appl. Microbiol., 108(6): 1889-1902. doi:10.1111/j. 1365-2672.2009.04590.x

Kurniawan, M., Izzati, M. \& Nurchayati, Y. 2010. Kandungan Klorofil, Karotenoid, dan Vitamin C pada Beberapa Spesies Tumbuhan Akuatik. Bul. Anatomi dan Fisiologi.18 (1): 28-40.

Laughlin, R.G., Bunke, G.M., Eads, C.D., Laidig, W.D. \& Shelley, J.C. 2002. Preparation and physical characterization of pure $\beta$-carotene. Chem. Phys. Lipids. 115(1): 63-76. doi: 10.1016/S00 09-3084(02)00008-7

Lee, E.J., Yoo, K.S. \& Patil, B.S., 2011. Total Carotenoid, Anthocyanin, and Sugar Contents in Sliced or Whole Purple (cv. BetaSweet) and Orange Carrots during 4-week Cold Storage. Holtic. Environ. Biotechnol. 52(4): 402-407. doi: 10.1007/s13580-011-0227-0

Magarvey, N.A., Keller, J.M., Bernan, V., Dworkin, M. \& Sherman, D.H., 2004 Isolation and Characterization of Novel Marine-Derived Actinomycetes Taxa Rich In Bioactive Metabolites. Appl. Environ. Microbiol. 70(12): 7520-7529. doi: 10.1128/AEM.70.12.75207529.2004

Musfiroh, I., Indriyati, W., Muchtaridi \& Setiya, Y. 2008. Analisis Proksimat dan Penetapan Kadar $\beta$-Karoten dalam Selai Lembaran Terung belanda (Cyphomandra betacea Sendtn.) dengan Metode Spektrofotometri Sinar Tampak. Fakultas Farmasi Universitas Padjadjaran. 367pp. 
Nugraheni, S.A., Khoeri, M.M., Kusmita, L., Widyastuti, Y. \& Radjasa, O.K., 2010. Characterization of Carotenoid Pigments from Bacterial Symbionts of Seagrass Thalassia hemprichii. J. Coas. Dev. 14(1): 51-60.

Palanichamy, V., Hundet, A., Mitra, B. \& Reddy, N. 2011. Optimization of Cultivation Parameters for Growth and Pigment Production by Streptomyces spp. Isolated From Marine Sediment and Rhizosphere Soil. Int. J. Plant. Anim. Environ. Sci. 1 (3): 158-170.

Rizkina, R.A., Yudiati, E. \& Sedjati, S. 2013. Uji Toksisitas Ekstrak Pigmen Kasar Mikroalga Spirulina platensis Dengan Metode Uji BSLT (Brine Shrimp Lethality Test). J. Mar. Res. 2(1): 25-31.

Rodriguez-Amaya, D.B., 2001. A guide to carotenoid analysis in foods. Washington, DC: ILSI press.
Sahara, F.N.I., Radjasa, O.K. \& Supriyantini, E. 2013. Identifikasi Pigmen Karotenoid Pada Bakteri Simbion Rumput Laut Kappahycus alvarezii. J. Mar. Res. 2(3): 58-67.

Shindo, K. \& Misawa., N. 2014. New and Rare Carotenoids Isolated from Marine Bacteria and Their Antioxidant Activities. Mar. Drugs. 12: 1690-1698; doi: 10.3390/md12031690

Simova, E.D., Frengova, G.I. \& Beshkova, D.M., 2004. Synthesis of carotenoids by Rhodotorula rubra GED8 co-cultured with yogurt starter cultures in whey ultrafiltrate. J. Indus. I Microbiol. Biotechnol. 31(3): 115-121. doi: 10. 1007/s10295-004-0122-0

Zhang, Y., Ji, Y., Jiang, X., Xu, S., Zhu, Z., Zheng, L., He, J., Ling, H., Wang, Y., Liu, Y. \& Du, W., 2008. Genetic characterization of measles viruses in China, 2004. Virol. J. 5(1): 120-125. 